\section{Analogia entis}

\section{v nominalistické}

\section{tradici.}

\section{Poznámky na}

\section{okraj sémantiky}

14. století

ANALOGIA ENTIS IN THE NOMINALIST

TRADITION. MARGINAL NOTES ON

FOURTEENTH-CENTURY SEMANTICS

\section{MIROSLAV HANKE}

Filosofický ústav Akademie věd ČR, v.v.i.

Jilská 1

11000 Praha 1

hanke@flu.cas.cz

\section{ABSTRAKT}

The problem of the analogy of being is at an intersection of ontology and semantics. It can be motivated by the following aporia: the assumptions that "being" is meaningful and transcendental and that every super-ordinate concept decomposes into specific concepts by means of specific differences are inconsistent. The solution is to reconsider the semantics of "being" or the theory of the generality of concepts. Since the thirteenth century, the former was associated with the view that the concept of being is transcendental but (systematically) ambiguous, while the latter with the view that the concept of being is transcendental and unambiguous but does not decompose into sub-ordinate concepts in the same way as generic concepts decompose into specific ones. One of the achievements of fourteenthcentury nominalism was an emphasis on semantics, which made it possible to re-formulate the analogy of being in rigorous logico-semantic terms. Second, the combination of Eucharistic ontology and a weak ontology of accidental beings led to a re-statement of the problem in a bottom-up fashion and to its re-construction into a theorem of the semantics and ontology of accidents. 


\section{I. ÚVOD}

Problém analogie jsoucna lze v rámci aristotelsko-scholastické tradice systematicky motivovat následujícím zpo̊sobem: Existují tři alespoň na první pohled související problémy, totiž transcendentálnost určitých pojmů (tj. jejich maximální obecnost a aplikovatelnost na všechny reálné objekty), kategoriální analýza a teorie obecnosti. Zaprvé, transcendentální pojmy, např. výrazy „jsoucno“, „jedno“ nebo „dobré“ jsou smysluplné. Zadruhé, „jsoucno“ se „dělí“ na deset kategorií: logicky vzato, výraz „jsoucno“ je pravdivě predikovatelný o výrazech spadajících do různých kategorií, takže je v určitém smyslu „obecnějšíi“ nežli výrazy spadající do jednotlivých kategorií. ${ }^{1}$

1 Otázka „dostatečnosti kategoriī“ (zda kategorií je právě deset, nebo nikoli a proč) bude nechána stranou.
Zatřetí, teorie „obecnosti“ je založena na Porfyriově teorii predikabilií: výrazy lze seřadit z hlediska obecnosti tak, že nadřazený termín je „rodem“ vůči podřazenému „druhu“, přičemž „rod“ je specifikován připojením „diference“ („živočich“ je specifikován v „člověka“ připojením „rozumného“). Všechny tyto tři dílčí koncepce samostatně fungují hladce, nicméně jejich kombinace generuje tzv. aporii rodu:

„Ale ani jedno, ani jsoucno nemohou být jedním jediným rodem věcí. Vždyt' každá diference libovolného rodu musí existovat a být jedna. Avšak není možné, aby se druhy určitého rodu nebo dané rody samotné (bez druhů) vypovídaly o př́islušných diferencích. Proto jestliže je jedno či jsoucno rodem, není jedním ani jsoucnem diference. (Nejsou-li však rodem, 
nemohou být ani principem, jsou-li rody principem.)“2

První dva ze tří uvedených předpokladů implikují, že jsoucno (nebo pojem

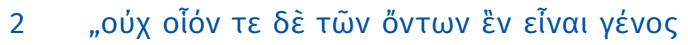

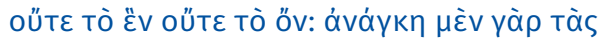

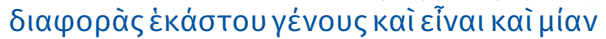

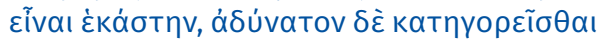

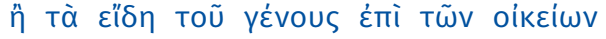

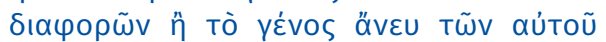

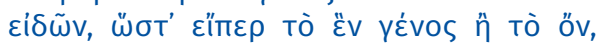

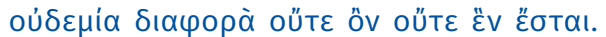

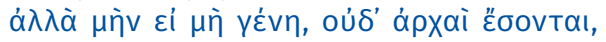

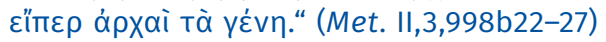
V překladu Viléma z Moerbeke: „Non est autem possibile genus existentium unum esse neque unum neque ens. Nam necesse differentias cuiuslibet generis et esse et unam esse quamlibet, impossibile autem predicari aut species GENERIS DE PROPRIIS differentiis aut genus sine suis speciebus; quare si unum genus aut ens, nulla differentia nec unum nec ens erit. AT UERO si non genera, nec principia erunt, si principia genera." (Aristoteles Latinus XXV 3.2 (1995, s. 56-57)) Český překlad se odklání od Křǐžova překladu (Met. II,3,998b22-27 (2008, s. 81)), který byl původně použit jako výchozí české znění; důvodem je snaha přibližit se jednak vyznění latinského překladu, jednak pozdějším středověkým interpretacím. Zmíním explicitně dvě změny oproti Křižovu překladu. Zaprvé, Křižův „rozdíl“ se změnil v („latinskou“) „diferenci“, což by mělo podpořit jeho technizaci (nejedná se o neutrální výraz, ale terminus technicus, který se ve scholastické logice stal součástí do latiny Boëthiem převedené porfyriovské teorie predikabilií). Zadruhé, ,jestliže je jedno či jsoucno rodem, není jedním ani jsoucnem diference“ nahrazuje Křižovo „kdyby jedno nebo jsoucno byly rodem, nemohla by ani jsoucnost, ani jednost být rozdílem“. Změna slovosledu posouvá důraz v textu tak, aby bylo zřejmé, že důsledek toho, že jsoucno (nebo výraz „jsoucno“) je rodem, je, že diference nejsou reálné, neexistují, což podporuje např. Akvinského čtení této pasáže. (Mimochodem Rossův překlad této věty zní: „so that if unity or being is a genus, no differentia will either be one or have being“ (Aristotelés 1985, s. 1577); tento posun je tedy možná v dobrém souladu i s „anglickým“ čtením Aristotela.) jsoucna) lze dělit na deset základních kategorií, a to bud'v tom smyslu, že existuje deset základních způsobů, jakými mimojazykové objekty existují (realistické, resp. ontologické čtení Kategorií), nebo v tom smyslu, že netranscendentální nesložené mimologické výrazy lze dělit do deseti skupin - kategorií - a pojem jsoucna je v nějakém smyslu slova „obecnější“ nežli kategoriální pojmy (nominalistické, resp. logické čtení Kategorií). Pokud je analýza obecnosti pojmů dána porfyriovskou teorií predikabilií (pokud jediný způsob, jakým může být jeden pojem nadřazen druhému, odpovídá způsobu, jakým je rod nadřazen druhu), vzniká uvedená aporie. ${ }^{3}$

Ve scholastické tradici se tomuto problému dostalo velké pozornosti přinejmenším počínaje rozvinutím teorie transcendentálií ve 13. století (které je tradičně spojováno s filozofickou reakcí na katarský dualismus) a působením zakladatelů pozdějších hlavních scholastických škol, totiž Alberta Velikého, Tomáše Akvinského, Dunse Scota a Viléma Ockhama. Po nastínění dvou paradigmatických strategií řešení aporie rodu, které formulovali Akvinský a Scotus, tato studie představí příspěvek $\mathrm{k}$ této diskuzi, jejž přinesl další vývoj v nominalistické tradici 14 . století, reprezentovaný zde texty „pařížských“ nominalistů Jana Buridana, Marsilia z Inghen a Mikuláše Oresmeho. ${ }^{4}$

3 Častým kontextem diskuze analogie jsoucna ve zkoumaných textech je právě otázka, jestli jsoucno je rod; tato formulace implicitně validuje „porfyriovský“ pohled na obecnost.

4 Ockhamova pozice a jeho vazba na Dunse Scota je rozebrána v Pelletier 2013, 


\section{REALISTICKÉ ROZVRŽENÍ PROBLÉMU (13. A 14. STOLETí)}

V realistickém provedení u Akvinského a Dunse Scota je diskuze o analogii jsoucna spojena s asociováním transcendentální analogie (existují substance a např. kvalita v tomtéž smyslu slova?)

s. 149-205. Od dalšîho z možných zdrojů relevantních pro daný okruh a období, Alberta ze Saska, se nedochovaly komentáře k Sentencím ani k Metafyzice. Co se týče jeho logických textů, Perutilis logica obsahuje stručnou zmínku o problému ekvivocity termínu "jsoucno“ a celou diskuzi odkazuje do „kvestiī“ (utrum autem iste terminus ens sit terminus aequivocus vel non, videbitur alibi in quaestionibus), srov. Albert ze Saska, Logik, tract. I.12 (2010, s. 90). Jeho Quaestiones super logicam se však problému podrobněji nevěnují a Quaestiones in artem veterem obsahují jen stručnou poznámku, že „jsoucno“ není nejvyšší rod (tzn. že deset aristotelských kategorií nelze redukovat na jednu „superkategorii“, totiž „,jsoucno“) v kontextu problému „dostatečnosti kategoriiَ“ (srov. Albert ze Saska, Quaestiones in artem veterem, (1988, s. 304 a 322)), a v kontextu analýzy definice rodu tvrzení, že „jsoucno“ není rod (Albert ze Saska, Quaestiones in artem veterem (1988, s. 216 a 226)), v obou připadech proto, že „jsoucno“ není univoční termín. Z těchto důvodů se tato studie věnuje pouze uvedené trojici nominalistických autorů. Zde analyzovaný korpus textů je motivován snahou prezentovat řešení stejného problému u různých autorů bez ohledu na konkrétní povahu zdroje. Skutečnost, že Oresmeho pozice je obsažena v komentáři k Fyzice (jeho komentáře k Metafyzice, Sentencím či jeho logicko-sémantické spisy nejsou známy, tj. bud'to neexistují, nebo se nedochovaly, nebo dosud nebyly objeveny) nebo že zásadní pro pochopení Buridana či Marsilia z Inghen jsou teorie obsažené v jejich logických spisech, může poskytnout samostatnou informaci o povaze daných řešení a do jisté míry vysvětlit některé odchylky (různost dưrazů, absenci témat apod.). (Aktuální bibliografické přehledy ke studovanému okruhu autorů publikovala Olga Weijers 1994-2012.) a teologické analogie (existují Bůh a stvoření ve stejném smyslu slova?). ${ }^{5}$ Základní tři řešení každého $\mathrm{z}$ problémů jsou dány rozdílem mezi „univocitou“, tedy jednoznačností, „ekvivocitou“, tedy čistou víceznačností, a „analogií“, tedy systematickou víceznačností. Obecně řečeno, jazykový výraz je jednoznačný, víceznačný, nebo systematicky víceznačný, jestliže mu v různých kontextech odpovídá jeden pojem, různé pojmy, nebo různé pojmy, mezi nimiž existuje určitý vztah, nebo (možná přesněji) jeden pojem, který označuje své sémantické koreláty jako uspořádané tak, že u něj lze hovořit o primárním a sekundárním významu. ${ }^{6}$ Řešením obou problémů je tedy otázka, zda je v těchto různých kontextech pojem jsoucna jednoznačný, víceznačný, nebo systematicky víceznačný.

V principu jsou různá řešení problému transcendentální a teologické analogie volně kombinovatelná, ačkoli v praxi nemusejí být všechny odpovědi

Pro terminologii „dvojí analogie“ a rozbor sekundární literatury viz Aertsen 2012, s. 9.

6 Přehled scholastických teorií analogie nabízi (z novějších zdrojů) např. Ashworth 2013, z české sekundární literatury kolektivní monografie Dvořák 2007a. Na tomto místě je vhodné předeslat, že tato studie se nevěnuje systematicky všem problémům spojeným s teorií analogie (přesná klasifikace typů analogie, otázka, zda existuji analogické pojmy, nebo jen analogické termíny, zda analogický pojem může být skutečně jeden...), ale primárně usiluje o to, popsat podobu, již spor o analogii jsoucna nabyl u nominalistických autorů ve 14 . století, a diskuze o tomto problému u ostatních autorů je predstavena jen do té míry, pokud prissívá k osvětlení tohoto problému. 
stejně (filozoficky) atraktivní. Historicky vzato se transcendentální víceznačnost připisuje Porfyriovi. ${ }^{7}$ Teologickou víceznačnost lze předpokládat u autorů rozvíjejících teologii areopagitik (jejímž krajním vyústěním je teologie založená na mlčení) a Akvinský tento názor připisuje Maimonidovi. ${ }^{8}$ A jak je dobře známo, kombinaci teologické a transcendentální analogie zastává Akvinský, zatímco kombinaci teologické a transcendentální jednoznačnosti Duns Scotus. Tato korelace nicméně není ničím vynucená. Uvedeme jen dva příklady; teologická jednoznačnost je slučitelná s transcendentální analogií, protože oba koncepty

Pravděpodobným zdrojem tohoto názoru je následující pasáž z jeho Isagogé, tj. Úvodu ke Kategoriím: „oú yá $\rho$ ÉoTı

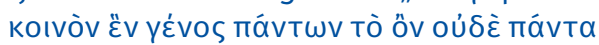

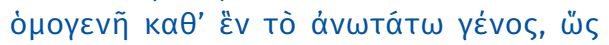

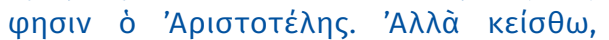

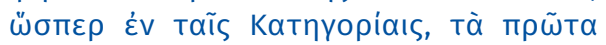

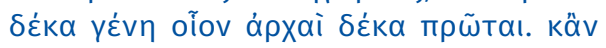

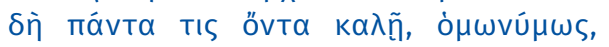

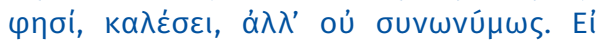
$\mu \varepsilon \grave{v}$ yà

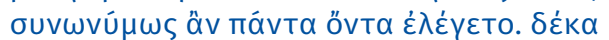

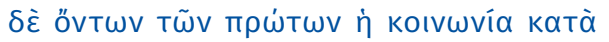

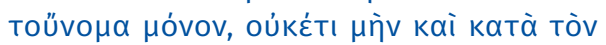

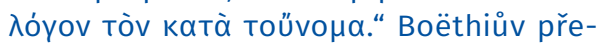
klad: „Neque enim est commune unum genus omnium ens, nec omnia eiusdem generis sunt secundum unum supremum genus, quemadmodum dicit Aristoteles. Sed sint posita, quemadmodum in Praedicamentis, prima decem genera quasi prima decem principia; vel si omnia quis entia vocet, aequiuoce, inquit, nuncupabit, non univoce. Si enim unum esset commune omnium genus ens, univoce entia dicerentur; cum vero decem sint prima, communio secundum nomen est solum, non etiam secundum definitionis rationem, quae secundum nomen est." Porphyrius, Isagoge (1998, s. 7-8). jsou motivovány řešením odlišných problémů: Můžeme předpokládat neproblematickou poznatelnost Boha (at' už z jakýchkoli důvodů) a zároveň tvrdit, že řešení aporie rodu vyžaduje zavedení transcendentální analogie. Podobně lze předpokládat transcendentální jednoznačnost $\mathrm{v}$ rámci nějakého řešení aporie rodu (pokud zavedeme revidovanou teorii obecnosti) a zároveň (např. motivováni studiem areopagitik) teologickou víceznačnost nebo (motivováni tezí, že každá příčina vyvolává sobě podobný účinek) analogii.

Tomáš Akvinský se k problému analogie vyjadřuje v řadě textů (a kontextů) z různých fází své akademické dráhy. Pro účely této studie byly vybrány čtyři formulace utvářející koherentní teorii kombinující transcendentální a teologickou analogii. ${ }^{9}$ Zaprvé, Tomášova interpretace aporie rodu v Contra Gentiles je založená na následujícím postupu: pokud je jsoucno rodem, musí existovat nějaká diference, která jej rozkládá v druhy. Diference, aby plnila tuto funkci, musí přitom být něco vnějšího vůči rodu; v opačném případě by byla diference zahrnuta $v$ rodu a definice daného druhu (složená z rodu a odpovídající diference) by obsahovala diferenci dvakrát (a tedy by byla nesprávně formulovaná). Pokud by tedy jsoucno bylo rodem, musely by existovat vưči němu vnější (tedy neexistující) diference, což je nemožné. Jsoucno tudíž není rodem. ${ }^{10}$

9 Reprezentativní soubor překladů do češtiny lze nalézt v Dvořák 2007c, k rozboru jeho pozice srov. Dvořák 2007b.

10 "Quod autem ens non possit esse genus, probatur per Philosophum in hunc 
Zadruhé, v Komentáři k Sentencím Tomáš zavádí specifickou teorii rozkládání nadřazených predikátů do podřazených, která je spojena s klasifikací predikátů na jednoznačné, víceznačné a analogické. Rozklad víceznačných predikátů se odvozuje od označovaných objektů, rozklad jednoznačných predikátů od diferencí a rozklad systematicky víceznačných predikátů od způsobů (resp. „modalit“). Predikát „jsoucno“ se jakožto analogický na kategorie rozkládá právě na základě různosti způsobů, konkrétně způsobů predikace (modus praedicandi). ${ }^{11}$ Zatřetí, v úvodní části Disputova-

modum. Si ens esset genus, oporteret differentiam aliquam inveniri per quam traheretur ad speciem. Nulla autem differentia participat genus, ita scilicet quod genus sit in ratione differentiae, quia sic genus poneretur bis in definitione speciei: sed oportet differentiam esse praeter id quod intelligitur in ratione generis. Nihil autem potest esse quod sit praeter id quod intelligitur per ens, si ens sit de intellectu eorum de quibus praedicatur. Et sic per nullam differentiam contrahi potest. Relinquitur igitur quod ens non sit genus." Tomáš Akvinský, Contra Gentiles, lib. 1, cap. 25.

11 "Ad secundum dicendum, quod aliter dividitur aequivocum, analogum et univocum. Aequivocum enim dividitur secundum res significatas; univocum vero dividitur secundum differentias; sed analogum dividitur secundum diversos modos. Unde cum ens praedicetur analogice de decem generibus, dividitur in ea secundum diversos modos. Unde unicuique generi debetur proprius modus praedicandi.“ Tomáš Akvinský, Scriptum super libros Sententiarum, lib. 1, d. 22, q. 1, art. 3, ad 2. Index Thomisticus, uvádějící různé výskyty fráze modus praedicandi, neumožňuje bližši výklad tohoto termínu, který by zároveň neodkazoval na teorii kategorií. Jedná se tedy o propojené problémy, které nejsou redukovány na základnější rovinu. Je pravděpodobné, že obecnější teorie nebyla ných otázek o pravdě Tomáš zavádí pojem jsoucna jako nejobecnější a (tedy) primární, z něhož jsou další pojmy utvářeny doplňováním. Toto „doplňování“ však není přidáváním vnějších určení (addi extranea), protože taková neexistují, nýbrž modifikací, tj. připojováním modalit (modi essendi, modi entis), které v samotném obecném pojmu jsoucna nejsou explikovány. Kategorie jsou pak jednoduše zvláštní modality existence (např. kategorie substance vyjadřuje samostatnost existence).${ }^{12}$ Začtvrté, v Disputovaných otázkách o moci se Tomáš ve stejném kontextu přihlašuje jak k transcendentální, tak k teologické analogii ${ }^{13}$

u Tomáše zavedena, protože přislušné texty (mezi nimiž proporčně převažuje právě Komentář $k$ Sentencím) obsahují pouze konkrétní aplikace.

12 ,[...] oportet quod omnes aliae conceptiones intellectus accipiantur ex additione ad ens. Sed enti non possunt addi aliqua quasi extranea per modum quo differentia additur generi, vel accidens subiecto, quia quaelibet natura est essentialiter ens; unde probat etiam philosophus in III Metaphys., quod ens non potest esse genus, sed secundum hoc aliqua dicuntur addere super ens, in quantum exprimunt modum ipsius entis qui nomine entis non exprimitur. Quod dupliciter contingit: uno modo ut modus expressus sit aliquis specialis modus entis. Sunt enim diversi gradus entitatis, secundum quos accipiuntur diversi modi essendi, et iuxta hos modos accipiuntur diversa rerum genera. Substantia enim non addit super ens aliquam differentiam, quae designet aliquam naturam superadditam enti, sed nomine substantiae exprimitur specialis quidam modus essendi, scilicet per se ens; et ita est in aliis generibus." Tomáš Akvinský, De veritate, q. 1, a. 1, co.

13 „Et praeterea ens non dicitur univoce de substantia et accidente, propter hoc quod substantia est ens tamquam per se habens esse, accidens vero tamquam cuius esse est inesse. Ex quo patet quod 
a uvádí dva typově klíčové argumenty pro analogii teologickou (přičemž aporii rodu a teorii modalit existence lze považovat za implicitní argumentaci pro transcendentální analogii): Zaprvé, epistemologický argument, resp. svého druhu transcendentální argument ve smyslu argumentu, který dokazuje $\mathrm{X}$ tím, že jej interpretuje jako podmínku smysluplnosti určité praxe. Jeho výchozím bodem je odmítnutí teologické jednoznačnosti (mezi Bohem a stvořením existuje kauzální vazba, která však nezakládá shodnost). Existují zastánci teologické víceznačnosti (Tomáš jmenuje Maimonida). Teologická víceznačnost by však implikovala, že celá teologie je zamořena paralogismy, protože veškeré naše poznání Boha se odvozuje od poznání stvoření. Zbývá tedy jediná možnost, jíž je teologická analogie. ${ }^{14}$ Zadruhé, ontologický argument, založený na předpokladu „kauzální similarity“: přestože kauzální vztah mezi

diversa habitudo ad esse impedit univocam praedicationem entis. Deus autem alio modo se habet ad esse quam aliqua alia creatura; nam ipse est suum esse, quod nulli alii creaturae competit. Unde nullo modo univoce de Deo et creatura dicitur; et per consequens nec aliquid aliorum praedicabilium inter quae est ipsum primum ens. Existente enim diversitate in primo, oportet in aliis diversitatem inveniri; unde de substantia et accidente nihil univoce praedicatur.“ Tomáš Akvinský, De potentia, q. 7, art. 7, co.

„Item, cum omnis cognitio nostra de Deo ex creaturis sumatur, si non erit convenientia nisi in nomine tantum, nihil de Deo sciremus nisi nomina tantum vana, quibus res non subesset. Sequeretur etiam quod omnes demonstrationes a philosophis datae de Deo, essent sophisticae [...] “ Tomáš Akvinský, De potentia, q. 7, art. 7, co.
Bohem a stvořením neimplikuje jejich shodnost, zaručuje (slabší) podobnost, která je postačujícím garantem teologické analogie. ${ }^{15}$ (A pokud by v rámci dané ontologie bylo možno udat nějakou formu kauzálního vztahu mezi substancí a akcidentem, bylo by podobným zpo̊sobem možno dokázat analogii transcendentální.)

Duns Scotus formuluje svou teorii teologické a transcendentální jednoznačnosti (resp. její podle všeho finální verzi) ve třetí distinkci první části Ordinatia, ${ }^{16}$ kde za zásadní argumentační postup lze označit postup epistemologický (a logický), což je dáno již kontextem, jímž je problém poznatelnosti Boha in statu viatori. Argumentace je zahájena vymezením jednoznačnosti relevantní pro daný kontext: jednoznačnost pojmu je to, co zaručuje, že je-li o tomtéž vypovídáno pozitivně i negativně, vzniká logický spor, a vykazuje-li jednoznač-

„Et praeterea oportet causatum esse aliqualiter simile causae; unde oportet de causato et causa nihil pure aequivoce praedicari, sicut sanum de medicina et animali. Et ideo aliter dicendum est, quod de Deo et creatura nihil praedicetur univoce; non tamen ea quae communiter praedicantur, pure aequivoce praedicantur, sed analogice." Tomáš Akvinský, De potentia, q. 7, art. 7, co.

16 Předběžnou a stručnější verzí je pak pochopitelně Scotova Lectura, ke které se zde nebudu odkazovat. Literatura k jakékoli části filozofie a teologie Dunse Scota je pochopitelně opět rozsáhlá. Z novějších českých zdrojů lze uvést knihy Sousedík 1989 a nově Novák 2011 (která obsahuje podrobné reflexe současné sekundární literatury). Specificky se pak problému analogie u Dunse Scota věnují Chabada 2007 a Novák 2007 (kde je formulována „skotistická“ pozice na základě poststředověké diskuze). 
nost střední termín sylogismu, nedochází k falácii víceznačnosti. ${ }^{17}$ Implicitně se zde tedy opakuje (a zesiluje) Tomášův postup: ${ }^{18}$ pro jednoznačnost (teologickou a transcendentální) argumentujeme proto, abychom se vyhnuli paralogismům (v teologii a metafyzice). Obecnou strukturu Scotových argumentů lze zformulovat takto: Veškeré poznání Boha se odvozuje z poznání stvoření (a veškeré poznání substancí se odvozuje z poznání akcidentů). ${ }^{19}$ Konkrétně (v př́ípadě poznání Boha): Bůh je poznáván tak, že je poznána určitá vlastnost, z níž jsou odfiltrována omezení, a takto pročištěná vlastnost je připsána Bohu. ${ }^{20} \mathrm{Jak}$ by

„Et ne fiat contentio de nomine univocationis, univocum conceptum dico, qui ita est unus quod eius unitas sufficit ad contradictionem, affirmando et negando ipsum de eodem; sufficit etiam pro medio syllogistico, ut extrema unita in medio sic uno sine fallacia aequivocationis concludantur inter se uniri.“ Duns Scotus, Ordinatio I., dist. 3, pars 1a, q. 2, no. 26.

18 Historicky vzato se však Scotova teorie jednoznačnosti a kritika analogie obrací proti Jindřichovi z Ghentu (Chabada 2007, s. 119).

19 ,[...] Deus non est cognoscibilis a nobis naturaliter nisi ens sit univocum creato et increato, ita potest argui de substantia et accidente. Si enim substantia non immutat immediate intellectum nostrum ad aliquam intellectionem sui, sed tantum accidens sensibile, sequitur quod nullum conceptum quiditativum poterimus habere de illa nisi aliquis talis possit abstrahi a conceptu accidentis; sed nullus talis quiditativus abstrahibilis a conceptu accidentis est, nisi conceptus entis." Duns Scotus, Ordinatio I., dist. 3, pars 1a, q. 3, no. 139 .

20 „[...] omnis inquisitio metaphysica de Deo sic procedit, considerando formalem rationem alicuius et auferendo ab illa ratione formali imperfectionem quam habet in creaturis, et reservando illam rationem formalem et attribuendo sibi tedy v tomto procesu mohlo docházet ke vzniku něčeho jiného nežli jednoznačných pojmů? Nebo z druhé strany: Je možné předpokládat, že Bůh existuje, avšak nevědět, zda je konečný, či nekonečný a stvořený, či nestvořený? Pojem jsoucna je tedy sám o sobě neutrální vưči rozdílu mezi konečným a nekonečným nebo stvořeným a nestvořeným. Jinými slovy, pojem jsoucna je vůči těmto různým aplikacím jednoznačný. ${ }^{21} \mathrm{Je}$-li však pojem jsoucna nezávislý na rozlišení mezi konečným a nekonečným atd., nelze u něj hovořit o analogii, která by předpokládala, že jedna z těchto dvou

omnino summam perfectionem, et sic attribuendo illud Deo. Exemplum de formali ratione sapientiae (vel intellectus) vel voluntatis: consideratur enim in se et secundum se; et ex hoc quod ista ratio non concludit formaliter imperfectionem aliquam nec limitationem, removentur ab ipsa imperfectiones quae concomitantur eam in creaturis, et reservata eadem ratione sapientiae et voluntatis attribuuntur ista Deo perfectissime. Ergo omnis inquisitio de Deo supponit intellectum habere conceptum eundem, univocum, quem accepit ex creaturis." Duns Scotus, Ordinatio I., dist. 3, pars 1a, q. 2, no. 39.

21 „Sed intellectus viatoris potest esse certus de Deo quod sit ens, dubitando de ente finito vel infinito, creato vel increato; ergo conceptus entis de Deo est alius a conceptu isto et illo, et ita neuter ex se et in utroque illorum includitur; igitur univocus." Duns Scotus, Ordinatio I., dist. 3, pars 1a, q. 2, no. 27. Takto vybudovaná argumentace má zajímavý potenciál, který překračuje kontext "skotismu“: epistemická nezávislost (doložená nezávislostí poznání Boží existence na poznání Boží konečnosti/nekonečnosti, stvořenosti/ nestvořenosti) je použita jako důkaz pojmové nezávislosti „jsoucna“ na rozlišení mezi konečností a nekonečností. Druhou stranou téže mince je předpoklad, že výrazy, které nejsou synonymní (tj. nevyjadřují tentýž pojem), nejsou v epistemických kontextech zaměnitelné. 
možností je termínem „jsoucno“ označována „primárně“. Konečně, v rámci alternativní teorie obecnosti je pojem jsoucna rozkládán do podřazených pojmů na základě „vnitřní modifikace“: výraz „konečný“ modifikuje výraz „jsoucno“ podobně jako vyjádření pro stupeň intenzity modifikuje výraz „bílý“.22 Skotistické „vnitřní mody“ tak v teorii obecnosti nahrazují aristotelsko-porfyriovské druhové diference (přinejmenším v tomto kontextu).

\section{JAN BURIDAN: KOMENTÁ- Г̌(E) KMETAFYZICE}

Řešení problému analogie jsoucna u Jana Buridana (cca 1300-1360) je průsečíkem (přinejmenším) dvou různých oblastí, totiž teologie a sémantiky. Současný konsenzus je, že Buridan se teologii profesionálně nevěnoval, takže specializované texty na toto téma od něj nejsou známy nejen proto, že dosud nebyly objeveny, ale protože nikdy nevznikly. ${ }^{23}$ Sémantikou kategoriální analýzy a teorií predikabilií se Buridan

„[...], infinitum ${ }^{\prime}$ non est quasi attributum vel passio entis, sive eius de quo dicitur, sed dicit modum intrinsecum illius entitatis, ita quod cum dico, infinitum ens', non habeo conceptum quasi per accidens, ex subiecto et passione, sed conceptum per se subiecti in certo gradu perfectionis, scilicet infinitatis, - sicut albedo intensa non dicit conceptum per accidens sicut albedo visibilis, immo intensio dicit gradum intrinsecum albedinis in se. Et ita patet simpli citas huius conceptus, ens infinitum:“ Duns Scotus, Ordinatio I., dist. 3, pars 1a, q. 2, no. 58.

Základním bibliografickým zdrojem k Buridanovi je ještě stále Michael 1985, nejaktuálnějším přehledem je Zupko 2014. K otázce Buridanova studia na „vyšších fakultách“ srov. Courtenay 2004, s. 16-17. zabýval v několika textech, sepsaných podle všeho $\mathrm{v}$ různých fázích jeho akademické dráhy, totiž v příslušných kapitolách rozsáhlých Summulae de dialectica a kvestiích k Isagogé a Kategoriím. Základními kontexty pro problém analogie jsoucna jsou Buridanovy Komentáře $k$ Metafyzice. Existuje několik různých řad těchto komentářů $\mathrm{v}$ návaznosti na různé kurzy, které Buridan na toto téma na pařížské univerzitě vedl. Jako textová evidence zde budou použity dvě textové varianty; starší, již de Rijk vydal pod názvem Lectura Erfordiensis, a novější, Lectio ultima, která vyšla tiskem na počátku 16. století a jejíž pro tuto studii relevantní část vydal Paul Bakker.

Lectura Erfordiensis obsahuje desátou otázku s titulem, „zdali může existovat jeden pojem společný substancím a akcidentům" (utrum possit esse unus conceptus communis substantiis et accidentibus). Její řešení je rozděleno na dvě části, totiž na odpověd' „v aristotelském duchu“ (secundum intentionem Aristotelis) a na výhradu, již implikuje křestanská teologie (fides nostra). Filozofická část řešení je shrnuta do tří základních tezí:

[LE1] Existuje pojem, jímž je zároveň uchopena substance a akcident, ty jsou však uchopeny různým, nikoli stejným způsobem. ${ }^{24}$

[LE2] Existuje konotativní pojem, který uchopuje substance a akcidenty stejným způsobem. ${ }^{25}$

24 „Et primo dico quod est dare conceptum unum quo simul concipitur substantia est accidens, non tamen indifferenter sed differenter." Jan Buridan, Lectura Erfordiensis, q. 10 (2008, s. 87).

25 "Secundo videtur michi esse dicendum quod est dare conceptum unum 
[LE3] Transcendentální výrazy (jako „věc“, „něco“, „jsoucno“ ve smyslu podstatného jména) nejsou odvozeny od jediného, primárního pojmu zastupujícího substance a akcidenty. ${ }^{26}$

První teze je založena na Buridanově sémantice akcidentálních výrazů jako „bílé“ či „tuponosé“. V konkrétních větných kontextech (např. ve větě „,toto kotě je bílé“) slovo „bílé“ zastupuje („suponuje“ za) určitou substanci a „,apeluje“ bělost a jak tato bělost, tak její nositel jsou reprezentovány výrazem „bílé“. Obě tyto sémantické vlastnosti, supozice a apelace, pak musejí mít nějaký pojmový základ, od něhož se odvozuje „signifikace“ a „konotace“27 (podle uvedeného př́́kladu „tuponosost“ signifikuje to, za co suponuje, totiž tvar nosu, a konotuje nos). ${ }^{28}$ Oproti tomu výrazům spadajícím do kategorie substance (jako

connotativum supponentem pro substantiis est accidentibus indifferenter." Jan Buridan, Lectura Erfordiensis, q. 10 (2008, s. 87).

26 „Sed tertia conclusio poneretur [...] quod nullus est conceptus primus supponens pro substantia et accidente a quo sumitur hoc nomen ,aliquid“ vel hoc nomen ,res‘ vel hoc nomen ,ens' [...]“ Jan Buridan, Lectura Erfordiensis, q. 10 (2008, s. 88).

27 Signifikace a konotace jsou tedy $v$ tomto pojetí nekontextuální sémantické vlastnosti (vlastnosti, které má výraz bez ohledu na větný kontext, v němž je použit) plnící funkci pojmové reprezentace objektu, kterým v konkrétním větném kontextu odpovídají supozice a apelace jakožto formy referování k objektu.

28 Lectura Erfordiensis, q. 10 (2008, s. 87). Ve svých logických spisech Buridan naznačuje (na pozadí téže teorie predikace) možnost, že (přinejmenším některé) abstraktní akcidentální termíny, jako např. „bělost“, mají podobnou sémantickou strukturu jako substanciální termíny, nicméně tuto myšlenku dále nerozvíjí jsou „člověk“, „kočka“, „kámen“) lze připsat pouze jednu z těchto vlastností, totiž signifikaci. ${ }^{29}$ Různost těchto sémantických funkcí je výkladem klauzule „různým zpo̊sobem“. Pochopitelně tato odpověd' nevyčerpává celý problém transcendentální analýzy (přesněji: vůbec se jí netýká), dobře však ukazuje celkovou Buridanovu metodu řešení problému.

Druhá teze pokrývá specifickou podobu transcendentální analýzy, totiž transcendentálnost některých relačních pojmů; konkrétními příklady jsou „totožné“, „různé“, „prvotní", „druhotné“ a „příčina“. Buridan uvádí několik konkrétních aplikací těchto pojmů na substance a akcidenty a u všech opakuje, že tyto pojmy jsou v těchto různých kontextech používány jednoznačně a stejným způsobem. ${ }^{30} \mathrm{~V}$ tomto případě se jedná o zajímavé rozpracování teorie transcendentálií: bez ohledu na výsledek argumentace pro tradiční metafyzické pojmy jsou transcendentální relační výrazy považovány za jednoznačné.

Pro třetí tezi Buridan argumentuje na základě dvou předpokladů odvozených ze sémantické kategoriální

(Jan Buridan, Summulae de suppositionibus, 4.1.4).

29 Pro přehledové shrnutí scholastické sémantiky termínů srov. Read 2015. Pro přibližnou představu lze problém formulovat tak, že „substanciální“ termíny označuji unární funkce, zatímco „akcidentální“ označuji funkce (přinejmenším) binární; akcidentální termíny jsou tedy ve specifickém smyslu slova relační. Striktně vzato je toto přibližení v Buridanově případě zavádějící, ale pro účely této studie se jedná o přijatelnou aproximaci.

30 Jan Buridan, Lectura Erfordiensis, q. 10 (2008, s. 87-88). 
analýzy a z teorie predikace (tedy ze sémantického čtení Kategorií a Isagogé). Zaprvé, pojmy se dělí do kategorií podle sémantických kritérií. „Aristotelova pozice“ je podle Buridanovy intepretace založena na tom, že zatímco „kámen“ vyjadřuje, že věc je něčím (esse aliquid), výraz „bílé“ vyjadřuje, že věc je nějaká (esse aliquale). Tyto rozdílné formy „konotace“, které zakládají rozlišení jednotlivých kategorií, jsou přitom považovány za vzájemně neredukovatelné. Zadruhé, na příkladech je stručně zavedeno rozlišení mezi esenciální a neesenciální predikací (kterou jinde Buridan nazývá „denominativní“). Příkladem esenciální predikace jsou věty „být člověkem je být živočichem“ nebo „být bílým je být barevným“, zatímco příkladem neesenciální predikace jsou věty jako „bílé je člověkem". ${ }^{31} \mathrm{~V}$ rámci těchto sémantických předpokladů je nemožné, aby existoval pojem esenciálně predikovatelný o pojmech spadajících do různých kategorií. ${ }^{32}$ Celou Buridanovu pozici lze shrnout do následujícího myšlenkového postupu: 1. Kategoriální analýza je sémantická teorie a kategorie jsou děleny na základě (gramaticko-)sémantických

Potud Buridanova sémantika kategorií a predikace $v$ jeho Metafyzice. Podrobnější analýzu lze nalézt v jeho logických spisech, tj. v kvestiích ke Kategoriím a k lsagogé a v příslušných částech Summulae de dialectica.

„Modo non est idem conceptus secundum quem intelligo esse aliquid et esse quale et quantum, et sic de aliis. Ideo nullus videtur conceptus quiditativus substantiarum et accidentium ut est aliquod nomen essentialiter predicativum de terminus substantialibus et accidentalibus." Jan Buridan, Lectura Erfordiensis, q. 10 (2008, s. 88). vlastností jazykových výrazů. 2. Kategorie jsou na sebe navzájem neredukovatelné. 3. Esenciální predikace jednoho termínu o druhém předpokládá, že oba termíny jsou zařaditelné do stejné kategorie. 4. Neexistuje termín, který by byl esenciálně predikovatelný o termínech spadajících do různých kategorií. 5. „Jsoucno“ není nejvyšším rodovým pojmem (protože nemůže být esenciálně predikován o termínech spadajících do různých kategorií).

Teologická výhrada, která tvoří druhou část Buridanovy odpovědi, představuje možné omezení jeho třetí teze. Jejím výchozím bodem je teologický předpoklad, že na základě Boží moci je možná existence akcidentů bez nositele, tzv. separovaných akcidentů, tedy ontologická interpretace eucharistie. Bělost existující samostatně v takovém případě není považována za akcidentální formu (protože neexistuje nic, co by se na jejím základě stávalo bílým a „v čem“ by existovala, přičemž „inexistence“ je standardní způsob existence akcidentů), ale za „něco“, tedy za specifický typ substance. Buridan dodává, že v tomto případě nic nebrání jednoznačnosti termínů, které jsou esenciálně vypovídány o substancích a takto samostatných akcidentech. ${ }^{33} \mathrm{Me}$ todologicky zajímavá je funkce tohoto argumentu: „Aristotelova“ teorie má být omezena (přinejmenším nemá platit pro některé akcidenty), a to na základě argumentů z víry. Postup je tedy takový, že „pravdy víry“ (resp. jejich ontologická

33 Jan Buridan, Lectura Erfordiensis, q. 10 (2008, s. 89-90). 
interpretace) mají epistemický primát vůči čistě filozofické teorii.

Z konceptuálně zajímavých argumentů lze upozornit na vstupní argument pro jednoznačnost transcendentálních termínů: zdá se, že pokud něco brání jednoznačnosti, je to závislost akcidentů na substancích. Závislost však nebrání teologické jednoznačnosti (Bohu i kameni lze podle Buridana připsat pojem substance), proto by neměla bránit ani transcendentální jednoznačnosti. ${ }^{34}$ Buridanova odpověd'odděluje problémy transcendentální a teologické analogie. Transcendentální analogie je založena na nemožnosti existence pojmu, který by bylo možno esenciálně predikovat jak o substanciálních, tak o akcidentálních pojmech, a to ze sémantických důvodů. $\mathrm{V}$ případě teologické analogie však tyto důvody nutně nenastávají: sémantika výrazů „Bůh“ a „kámen“ nebrání tomu, aby o obou bylo možno esenciálně predikovat výraz „substance“. ${ }^{35}$ Popření teologické analogie (ve prospěch teologické jednoznačnosti) je tak jedním ze zajímavých bodů Buridanovy argumentace. ${ }^{36}$ Jeho další odůvodnění by mohlo spočívat $v$ tom, že analogii je třeba prokázat tím, že ukážeme, co brání jednoznačnosti. V případě sémantické odlišnosti substanciálních a akcidentálních termínů se odpověd' nabízí, nicméně v teologickém kontextu by teprve bylo třeba takový důvod uvést. Fakticky Buridan teologickou

34 Jan Buridan, Lectura Erfordiensis, q. 10 (2008, s. 83).

35 Jan Buridan, Lectura Erfordiensis, q. 10 (2008, s. 90).

36 Objevuje se rovněž v Jan Buridan, Lectura Erfordiensis, q. 10 (2008, s. 220-221). jednoznačnost předpokládá (právě na jejím základě ukazuje, že priorita a odvozenost nejsou dostatečným základem pro analogii), zároveň však za jediné dobré odůvodnění analogie považuje odůvodnění sémantické.

Pozice, již předkládá Buridanova Lectura ultima, se (snad až na drobné terminologické odchylky) zásadně neodchyluje od pozice, již předkládá Lectura Erfordensis. ${ }^{37}$ Zajímavý je však jeden ze vstupních argumentů pro univocitu: pokud by pojem jsoucna nebyl jednoznačný, implikovalo by to nejednoznačnost principu sporu, která by ohrožovala jeho epistemický status primárního principu. ${ }^{38}$ Buridanova odpověd' spočívá $\mathrm{v}$ tom, že v principu sporu (v aristotelské formulaci znějící „totéž nemůže být a nebýt (něčím) v tomtéž smyslu“) se neobjevuje termín „jsoucno“, ale logická spona „být “ a různé formy slova „totéž“, tedy transcendentální relace, které však Buridan (přinejmenším ve svém starším textu) považuje za jednoznačné. ${ }^{39}$

Zajímavou odchylkou (resp. zajímavým rozšiřením) je, že Lectura ultima diskutuje povahu akcidentů ve vztahu k sémantice větných nominalizací (gramaticky vzato: akuzativně-infinitivních konstrukcí) jako esse album (Jan Buridan, Lectura Erfordiensis, q. 10 (2008, s. 228-229)). Toto propojení je blízké Oresmeho teorii akcidentů (ačkoli otázka vzájemného vlivu není v tuto chvíli vyjasněna). Rozborem ontologie akcidentů v této otázce a její komparaci s pozicí Marsilia z Inghen se specificky s ohledem na ontologický status akcidentů a institucionální aspekty vztahu filozofie a teologie zabývá Bakker 2000 a 2002.

Jan Buridan, Lectura ultima, lib. 4, q. 6 (2002, s. 220-221).

39 Jan Buridan, Lectura ultima, lib. 4, q. 6 (2002, s. 226-227). 
Obecně představuje Buridanův příspěvek $\mathrm{k}$ problému analogie jsoucna konkrétní kapitolu z aplikované sémantiky. Metafyzické problémy jsou zde nahlíženy jako triviální důsledky sémantických teorií. Zda tento krok znamená vyzdvižení sémantiky, nebo trivializaci metafyziky, lze ponechat na vkusu čtenáře.

\section{MARSILIUS Z INGHEN: KOMENTÁR̆ K ISAGOGÉ A KOMENTÁR̆ K METAFYZICE}

Marsilius z Inghen (cca 1340-1396) ${ }^{40}$ se problému analogie jsoucna věnuje ve dvou různých kontextech, totiž v sémantickém kontextu v Komentáři k Isagogé a v teologicko-ontologickém kontextu v Komentáři k Metafyzice. ${ }^{41}$

Devátá kvestie Marsiliova Komentáře k Isagogé „Utrum ens est genus?“ je rozdělena do dvou článků, z nichž první představuje obecné předpoklady a druhý podává odpověd' na položenou otázku.

První článek obsahuje dva předpoklady (suppositiones), podle Marsilia „uznané Aristotelem“, a jeden z nich vyvozený závěr (corollarium):

$40 \mathrm{~K}$ biografii a bibliografii Marsilia z Inghen srov. Hoenen 2017.

41 Z dalších, drobnějších kontextů lze uvést otázku týkající se „dostatečnosti kategoriī“ v Marsiliově Komentáři ke Kategoriím (Marsilius z Inghen, Quaestiones super librum Praedicamentorum Aristotelis, q. 26, ad 14 (2008, s. 387)). Problému teologické analogie (resp. různým druhům teologické analogie) se Marsilius věnuje $v$ Komentáři $k$ Sentencím (srov. např. Quaestiones super quattuor libros Sententiarum, lib. I, q. 12, art. 2 (2000, s. 94-107), kde se Marsilius věnuje otázce kategoriální analyzovatelnosti „Boha“, a lib. I, q. 28, art. 3 (2015, s. 169-171) k teologické analogičnosti výrazu „osoba“).
[QISup1] Termín „jsoucno“ signifikuje analogicky substanci a akcident, substanci prvotně a akcident druhotně. ${ }^{42}$

[QISup2] Analogický termín, který se ve větě vyskytuje bez další kvalifikace, zastupuje známější ze svých významů. ${ }^{43}$

[QICorr] Termín „jsoucno“, pokud se ve větě vyskytuje bez další kvalifikace, zastupuje substance; $v$ důsledku toho jsou věty „Sókratés je jsoucno“ a „Sókratés je substance" ekvivalentní. ${ }^{44}$

Tvrzení termínu „bez další kvalifikace“ (ponitur per se) se vymezuje proti „omezenému“ tvrzení, kdy je k určitému termínu připojen výraz provádějící „restrikci“, tj. v tomto př́ípadě ${ }^{45} \mathrm{změnu}$ sémantické funkce, kdy termín zastupuje svůj méně známý význam. ${ }^{46}$ První článek tedy předpokládá (s odkazem na Aristotela), že termín „jsoucno“ je vưči substancím a akcidentům analogický,

42 „Prima est ista, quod iste terminus, ens significat analogice substantiam et accidens.“ Marsilius z Inghen, Quaestiones super Isagogen Porphyrii (2014, s. 76).

43 "Secundo suppono, quod analogum positum per se stat pro modo famosiori.“ Marsilius z Inghen, Quaestiones super Isagogen Porphyrii (2014, s. 77).

44 „[...] quando iste terminus, ens‘ ponitur per se, stat pro substantia et quod aequivalet dicere ,Sor est ens' et ,So rest substantia“." Marsilius z Inghen, Quaestiones super Isagogen Porphyrii (2014, s. 77).

45 "Restrikce“ obvykle označuje spíše opak "ampliace“, tedy zúžení (oproti rozširení) souboru objektů, které termín zastupuje, vůči souboru objektů, které zastupovat může, vyvolané použitím temporálních či modálních výrazů. Typicky „člověk“ v „Každý člověk může nosit tričko“ zastupuje nejen skutečně existujicí, ale také minulé, budoucí a možné lidi. (Read 2015)

46 Marsilius z Inghen, Quaestiones super Isagogen Porphyrii (2014, s. 78). 
přičemž analogie je odvozena od vnitřní strukturace jeho významu.

Druhý článek obsahuje dva závěry (conclusio responsalis):

[QICo1] Výraz „jsoucno“ je rod. ${ }^{47}$

[QICo2] Výraz „jsoucno“ není rodem vůči všem (resp. vůči tradičním deseti) kategoriím. ${ }^{48}$

První je jednoduchou aplikací definice rodu jako termínu, který je jednoznačný, nesložený a predikovatelný in quid (tj. jako odpověd' na otázku, čím věc je) o tom, co je druhově odlišné (na základě nějakého nejkonkrétnějšího druhu). ${ }^{49}$ „Rod“ je tedy relační výraz: termín není „rodem“ sám o sobě, ale pouze ve vztahu $\mathrm{k}$ určitým termínům (je-li o nich uvedeným způsobem predikovatelný). Druhý závěr rozvíjí teze z prvního článku: analogický termín nemůže být rodem vůči všemu, co signifikuje, protože rodové termíny jsou z definice jednoznačné. Jestliže tedy „jsoucno“ označuje kategoriální entity analogicky, nemůže vůči nim být rodem.

Jeden z problémů, které toto řešení implikuje, je, že sémantika „jsoucna“ prezentovaná v prvním článku se zdá být $v$ rozporu s předpokladem transcendentality pojmu jsoucna (quomodo salvabitur, quod „ens“ est nomen transcendens).

47 ,[...] iste terminus, ens' est genus.“ Marsilius z Inghen, Quaestiones super Isagogen Porphyrii (2014, s. 78).

48 , $[. .$.$] iste terminus, ens { }^{\prime}$ non est genus ad omnia seu ad decem praedicamenta.“ Marsilius z Inghen, Quaestiones super Isagogen Porphyrii (2014, s. 79).

49 ,[...] terminus univocus, incomplexus, praedicabilis de pluribus differentibus specie specialissima [...] praedicatur in quid [...]“ Marsilius z Inghen, Quaestiones super Isagogen Porphyrii (2014, s. 78-79).
Marsilius odpovídá, že transcendentalita nepředpokládá jednoznačnost, pouze obecnou predikovatelnost. V případě termínu „jsoucno“ je toto zaručeno tím, že jej lze pravdivě predikovat jak o substanciálních, tak o akcidentálních termínech. Protože se však jedná o termín analogický, má svůj primární a sekundární význam, a pokud je tvrzen bez další kvalifikace, zastupuje substance, zatímco je-li $\mathrm{k}$ němu připojena kvalifikace, může zastupovat akcidenty (jako ve větě „bělost je inherentní jsoucno").${ }^{50}$ Konceptuálně zajímavým krokem je tedy oddělení transcendentality od univocity, přičemž lze předpokládat, že kdyby Marsilius zastával skotistické pojetí jsoucna, byl by nadále zastáncem jeho transcendentality.

Marsiliův Komentář k Metafyzice sdílí společná témata s Buridanovým Komentářem $k$ Metafyzice. Marsiliovo řešení otázky Utrum „ens“ univoce significet substantias et accidentia je rozděleno na prezentaci „obecně sdíleného názoru“ (připisovaného Buridanovi s poznámkou, že Buridan ke konci života svůj názor patrně změnil, a „mnohým teologům“ $)^{51}$ a „metafyzického stanoviska“.

První část jeho odpovědi je zformulována v osmi tezích (conclusiones):

[QMCo1] Podle Aristotela spočívá ontologický status akcidentů v inexistenci a akcidenty nemohou existovat samostatně. ${ }^{52}$

50 Marsilius z Inghen, Quaestiones super Isagogen Porphyrii (2014, s. 79).

51 Marsilius z Inghen, Quaestiones in Metaphysicam, IV, q. 5 (2002, s. 236).

52 ,[...] secundum Philosphum accidentis esse est purum inesse et nullo modo pos- 
[QMCo2] Podle filozofů se tedy akcidentům nepřipisuje absolutní existence, ale inexistence (,jsou v něčem nebo jsou něčím něčeho jiného"). ${ }^{53}$

[QMCo3] Aristotelés popírá esenciální shodnost mezi akcidenty a substancí. ${ }^{54}$

[QMCo4] Proto neexistuje substanci a akcidentu nadřazený esenciální pojem. ${ }^{55}$

[QMCo5] Ve skutečnosti mohou akcidenty existovat samostatně bez nositele. ${ }^{56}$

[QMCo6] Substance a akcident se tedy („ve skutečnosti“) shodují v tom, že mohou existovat samostatně. ${ }^{57}$

[QMCo7] Výraz „jsoucno“ je jednoznačný vůči řadě substancí a akcidentů, přinejmenším vůči těm, které mohou působením Boží moci existovat samostatně. ${ }^{58}$

se per se existere.“ Marsilius z Inghen, Quaestiones in Metaphysicam, IV, q. 5 (2002, s. 236).

53 „[...] ideo philosophi dicunt accidens non esse simpliciter, nec esse aliquid, sed pocius esse in alio vel aliquid alterius.“ Marsilius z Inghen, Quaestiones in Metaphysicam, IV, q. 5 (2002, s. 236).

54 „[...] iuxta mentem Aristotelis nulla est essentialis conuenientia accidenciu cum substancia." Marsilius z Inghen, Quaestiones in Metaphysicam, IV, q. 5 (2002, s. 236).

55 „[...] iuxta hanc viam Philosophi nullus potest esse conceptus essencialis simplex communis substancie et accidentibus." Marsilius z Inghen, Quaestiones in Metaphysicam, IV, q. 5 (2002, s. 237).

secundum rei veritatem accidentia possunt per se esse et sine subiecto existere." Marsilius z Inghen, Quaestiones in Metaphysicam, IV, q. 5 (2002, s. 237).

„[...] in posse per se existere conueniunt substancia et accidens." Marsilius z Inghen, Quaestiones in Metaphysicam, IV, q. 5 (2002, s. 237).

58 „[...] ens est vniuocum ad omnes substancias et omnia accidencia, saltem illa que possunt seorsum existere per potenciam
[QMCo8] „Jsoucno“ je nejobecnějším rodem vůči termínu „substance“ a ostatním termínům, které označují bez vztahu k něčemu dalšímu všechny akcidenty, jež mohou existovat samostatně. ${ }^{59}$

Jedná se o relativně přesnou parafrázi Buridanovy pozice, s jistým posunem v šesté a sedmé tezi: Marsilius zdůrazňuje, že shoda mezi substancí a akcidentem je založena na možné samostatnosti, nikoli na samostatnosti aktuální. Jedná se však o posun přípustný v rámci daného přístupu.

Vlastní Marsiliovo pojetí je shrnuto ve dvou základních tezích (conclusiones articuli), z nichž první je spíše interpretačního rázu, zatímco druhá je systematická:

[QMCoA1] Aristotelés nepopírá, že akcidenty jsou jsoucna $\mathrm{v}$ absolutním smyslu slova. ${ }^{60}$

[QMCoA2] Neexistuje jednoznačný pojem aplikovatelný na substanci i akcident. ${ }^{61}$

Druhá teze, která je systematicky závažnější, je založena na kognitivním základu esenciálních pojmů a esenciální

diuinam." Marsilius z Inghen, Quaestiones in Metaphysicam, IV, q. 5 (2002, s. 237).

59 ,[...] ens est genus generalissimum ad hunc terminum ,substantia‘ et alium terminum qui absolute significat omnia accidencia, saltem potencia per se existere, si esset ei nomen impositum.“ Marsilius z Inghen, Quaestiones in Metaphysicam, IV, q. 5 (2002, s. 237).

60 „[...] Philosophus non negauit accidencia esse encia simpliciter [...]" Marsilius z Inghen, Quaestiones in Metaphysicam, IV, q. 5 (2002, s. 238).

61 ".... nullus est conceptus vniuocus substancie et accidentis." Marsilius z Inghen, Quaestiones in Metaphysicam, IV, q. 5 (2002, s. 240). 
predikace: jednoznačný pojem je založen na esenciální podobnosti věcí ( fundatur super esenciali similitudine rerum). ${ }^{62}$ Mezi substancemi a akcidenty podobná podobnost existovat nemůže $\mathrm{z}$ důvodu rozdílu mezi substancemi a akcidenty co do způsobů, jimiž jsou závislé na Bohu (modus dependencie rerum a prima causa). ${ }^{63}$ Substanciální způsob závislosti na Bohu je založen na tom, že určitá věc existuje samostatně nebo konstituuje samostatně existující věc (jako esenciální složky substancí, tj. substanciální forma a jí odpovídající látka). Akcidentální způsob závislosti na Bohu spočívá v ovlivňování toho, co existuje prvním způsobem, přičemž akcidenty nemohou přirozeně (bez zázraku) existovat samostatně ani utvářet substanciální jednotu spolu se svým nositelem (tzn. substance a akcident nevytvářejí společně další substanci). Terminologicky zhuštěnou formou je potom rozlišení mezi esse per se a esse affectiue (použité i na výklad Aristotelovy pozice), resp. dependencia rerum per se existencium a dependencia rerum afficiencium vel disponencium substancias, z nichž je odvozena reálná samostatnost, resp. tendence $\mathrm{k}$ inexistenci nezakládající substanciální jednotu. Tato („esenciální“) odlišnost je pak podle Marsilia zachována bez ohledu na samostatnost existence, která může nastat

62 Marsilius z Inghen, Quaestiones in Metaphysicam, IV, q. 5 (2002, s. 240).

63 Spojení esence a v návaznosti na to esenciální shodnosti a odlišnosti se „způsobem závislosti na Bohu“ připomíná teorii Jindřicha z Ghentu, podle něhož je „esenciální bytí“ dáno vztahem věci k Bohu jakožto exemplární přičině (Jindřich z Ghentu, Quodlibeta, X, q. 7 (1981, s. 171)). v př́ípadě eucharistie i u akcidentů. ${ }^{64}$ Výsledkem je snaha formulovat rozdíl mezi substancí a ostatními kategoriemi bez ohledu na aktuální samostatnost a nesamostatnost, ale spíše s ohledem na vlastnost, která má samostatnost a nesamostatnost zakládat, a tak poskytnout koherentní integraci katolického pojetí eucharistie a aristotelské kategoriální analýzy.

\section{TÁR̆ K FYZICE}

Mikuláš Oresme (1320-1382) ${ }^{65}$ se problému analogie jsoucna věnuje ve svém Komentáři k Fyzice, v páté otázce k první knize, nazvané jednoduše „Utrum ens sit univocum ad substantiam et ad accidens“. Řešení otázky je rozděleno na tři části, na vstupní sémantické předpoklady, ontologicko-sémantické řešení položené otázky a rozbor souvisejících problémů.

První částí Oresmeho řešení je (fragment) teorie jednoznačnosti, víceznačnosti a analogie. Jejím základem je rozlišení mezi dvěma typy víceznačnosti, totiž náhodnou (equivocum a casu), kdy různé významy k sobě nemají žádný vztah, a analogickou, resp. systematickou (equivocum analogum), kdy různé významy lze uspořádat jako primární a sekundární, a to tak, že primárnost a sekundárnost je dána strukturou významu, nikoli (např.) dokonalostí označovaných entit. Toto rozlišení je potom rozvíjeno v pěti tezích (propositiones):

64 Marsilius z Inghen, Quaestiones in Metaphysicam, IV, q. 5 (2002, s. 240-241).

65 K Oresmeho biografii a bibliografii srov. Kirschner 2013. 
[QPP1] Víceznačnost je definována tak, že totéž slovo se vypovídá různými způsoby (ratio est diversa). ${ }^{66}$

[QPP2] Pokud „růzností způsobu“ rozumíme různost vyjádřených pojmů, pak uvedená definice odpovídá tzv. náhodné víceznačnosti. ${ }^{67}$

[QPP3] Analogická víceznačnost není nutně založena na pojmové různosti. ${ }^{68}$

[QPP4] „R̛̊zností způsobu“ Oresme chápe definiční odlišnost, především odlišnost v nominální definici (tzn. vymezení významu). ${ }^{69}$

[QPP5] Nutnou podmínkou toho, aby dva objekty bylo možno označovat jednoznačně, je přirozená podobnost, shoda či rovnost mezi těmito objekty. ${ }^{70}$

66 „[...] aliquid dicitur equivocum quando nomen est commune et ratio secundum illud nomen est diversa [...]" Oresme, Questiones super Physicam, I, q. 5 (2013, s. 32).

67 „[...] cum dicitur, ratio est diversa', si diceretur per, rationem conceptus, ita quod uni nomini vocali equivoco correspondent duo vel plures conceptus in mente, tunc esset verum de equivoco a casu [...]“ Oresme, Questiones super Physicam, I, q. 5 (2013, s. 32$)$.

68 „[...] non oportet de equivoco analogo quod correspondeant diversi conceptus, ita quod <possibile est quod> conceptus sit communis [...]“ Oresme, Questiones super Physicam, I, q. 5 (2013, s. 32).

69 „[...] quando dicitur: ,ratio <est> diversa', per ,rationem intelligitur definitio seu descriptio quid rei vel quid nominis, immo magis quid nominis [...]“ Oresme, Questiones super Physicam, I, q. 5 (2013, s. 33).

70 ,[...] ad hoc quod aliqua non sint significabilia univoce sed equivoce requiritur quod non habeant aliquam similitudinem naturalem seu convenientiam vel proportionem equalitatis [...]" Oresme, Questiones super Physicam, I, q. 5 (2013, s. 33).
Odvozenou tezí potom je, že pojmy (tj. mentální stavy) mohou být analogické, ačkoli nemohou být víceznačné; přirozená sémantičnost mentálního jazyka nevylučuje možnost, že přirozený význam je strukturován z hlediska primárnosti a sekundárnosti. ${ }^{71}$

Druhá část řešení odpovídá na otázku, zda existuje jednoznačný nadřazený pojem pro substance a akcidenty, což podle Oresmeho předpokládá vyjasnění ontologie substancí a akcidentů. Text obsahuje dvě vstupní terminologické poznámky (notanda) a čtyři závěry (conclusio). Oresme sám považuje problém za velmi obtížný a své vlastní řešení za pouhý návrh.

[QPNot1] Substance je to, co existuje ve vlastním smyslu slova, samostatně a co lze označit podstatným jménem. ${ }^{72}$

[QPNot2] Existují tři pojetí akcidentů (a Oresme se přiklání k poslednímu z nich): zaprvé, akcidenty jsou reálné formy inherentní substancím; zadruhé, akcidenty jsou totožné se substancemi majícími určité nahodilé rysy; zatřetí, akcidenty jsou stavy věcí, skutečnosti, že se substancemi se to má tak a tak. ${ }^{73}$

71 Oresme, Questiones super Physicam, q. 5 (2013, s. 33). Teze není dále rozvedena.

72 ,[...] substantia est res que per se existit et proprie; et ideo est aliquid signatum demonstrabile nomine substantie." Oresme, Questiones super Physicam, I, q. 5 (2013, s. 34$)$.

73 ,[...] accidens potest ymaginari tripliciter: uno modo quod sit vera forma inherens substantie [...] Secundo modo, quod accidens nullo modo preter animam sit alia res ab ipsa substantia subiecta, sed solum sit ipsa substantia taliter se habens [...] Tertia via alia est, et posset ymaginari [...] sed esset aliquid tale esse 
[QPCo1] Výraz „jsoucno“ se o substanci a akcidentu vypovídá analogicky, ve vlastním smyslu slova se vypovídá o substanci a sekundárně o akcidentu. ${ }^{74}$

[QPCo2] Je pravděpodobné (s jistými výhradami), že podle Aristotela neexistují akcidenty v prvním smyslu slova. ${ }^{75}$

[QPCo3] Žádný akcident není substancí. ${ }^{76}$

[QPCo4] Akcidenty ve vlastním smyslu slova jsou objekty typu „že něco je takové“, „že něco se vztahuje k něčemu“ atd. a není možno je vyjádřit pomocí podstatného jména. ${ }^{77}$

Druhý závěr (jako spíše interpretační) lze ponechat stranou. Pro první (a klíčový) závěr uvádí Oresme tři argumenty: Zaprvé, termín „jsoucno“ vykazuje určitý primární význam, jak

aut tantum esse.“ Oresme, Questiones super Physicam, I, q. 5 (2013, s. 34).

74 ,[...],ens` dicitur equivoce de substantia et accidente, capiendo,equivocum secundo modo pro analogo, ita quod proprie et vere dicitur de substantia, secund<ari>0 de accidente." Oresme, Questiones super Physicam, I, q. 5 (2013, s. 35).

75 „[...] probabiliter et cum correctione [...] quod de intentione Philosophi videtur quod nullum accidens est forma seu essentia secundum primam viam expositam in notabili sive primum modum.“ Oresme, Questiones super Physicam, I, q. 5 (2013, s. 36).

„[...] nullum accidens est substantia nec qualitas nec quantitas nec relatio etc." Oresme, Questiones super Physicam, I, q. 5 (2013, s. 37$)$.

77 ,[...] omne accidens proprie loquendo est aut tantum esse aut tale esse aut ad aliquid <esse> aut aliquod tale, que non sunt significabilia proprie aliquo communi nec aliquo nomine substantivo." Oresme, Questiones super Physicam, I, q. 5 (2013, s. 36$)$. potvrzují mluvčí, kteří na otázku „co je skutečné jsoucno“ odpovídají „substance“. Substance jsou tedy jsoucnem v primárním smyslu slova, takže význam slova „jsoucno“ je vnitřně strukturovaný, což implikuje analogii. Zadruhé, jednoznačnost předpokládá na straně označované reality přirozenou shodu či podobnost, což substance a akcidenty nesplňují. Argument (jehož obecný základ Oresme sdílí s Marsiliem) není dále rozveden, ale zdá se souviset s ontologií substancí a akcidentů. Zatřetí, jednoznačnost „jsoucna“ implikuje existenci jediné superkategorie, s čímž žádný z účastníků diskuze nesouhlasí.

Závěry tři a čtyři jsou prezentovány v opačném pořadí. Čtvrtý závěr je dále rozveden tvrzením, že akcidenty jsou označovány složenými výrazy, nikoli výrazy nesloženými. Oresme zároveň navrhuje jednotnou ontologii akcidentů, oproti ve 14 . století rozšířené snaze rozdělit akcidenty na reálně odlišné od svých nositelů a reálně identické se svými nositeli.

Podobně jako $v$ případě Buridana a Marsilia z Inghen je problém analogie řešen vyjasněním sémantiky a ontologie akcidentů, ${ }^{78}$ která v tomto případě nemá podobu analýzy separovaných

Oresmeho text vykazuje i další podobnosti s Buridanem a Marsiliem z Inghen. Za všechny jmenujme (do jisté míry Scotovým argumentem předznamenaný) argument pro jednoznačnost jsoucna na základě pochybnosti, zda X je substancí, či akcidentem, v situaci, kdy nepochybujeme, že $X$ je jsoucnem, nebo (zdánlivou) neslučitelnost analogie jsoucna s jednoznačností principu sporu (Oresme, Questiones super Physicam, I, q. 5 (2013, s. 31)). 
akcidentů (vázané na specificky teologický kontext), ale spíše podobu revoluční redefinice akcidentů jako propozičních objektů (stavů věcí, parametrů individuí...).$^{79}$ Ontologie propozic spadá do jiného kontextu a Oresme se tímto krokem zařazuje mezi autory 14 . století diskutující o ontologickém statusu významů vět. ${ }^{80}$ Přinejmenším terminologicky se nepřihlašuje $\mathrm{k}$ žádnému konkrétnímu stanovisku (termíny complexe significabile, condicio a modus rei používá bez snahy mezi nimi rozlišovat), nicméně tendence odlišit substance od akcidentů/ propozic, přestože ponechává řadu otevřených možností, je zřejmá. ${ }^{81}$

Pasnau tuto pozici označuje za „modální realismus“ (Pasnau 2012, s. 249 an.). Jistým předchůdcem tohoto názoru jsou Scotova Quodlibeta, kde se různé kategorie dělí na „věci“ (res), mezi něž patří substance, kvality a kvantity, a „modality věcí“ (modus rei), resp. „okolnosti“ (circumstantia) (srov. Duns Scotus, Quaestiones quodlibetales, q. 3 (1895, s. 115)). Z tohoto hlediska je Oresmeho modální realismus jednoduše dotažením Scotovy distinkce, zprostředkované ockhamovským redukcionismem. Zdá se, že tato distinkce má dvě různá historická vyústění: specificky pozdně středověkou, kde se termín modus rei poji s diskuzí o ontologickém statusu propozičních entit (jako u Oresmeho), a barokní (resp. raně novověkou), kde je zavedení modus rei dáno rozpracováním hylemorfistické teorie a nemá propoziční povahu (Leinsle 2002).

Nuchelmans 1988 podává přehled této diskuze ve 14. století (a další publikace téhož autora, jako Nuchelmans 1973 a 1980, tuto diskuzi mapují podrobněji), edici základních textů a jejich rozbor publikoval Dominik Perler (Perler 1990 a 1992). Středověkým katalogem různých pozic je na konci 14. století sepsaná Logica magna (Pavel z Benátek 1978). q. 13 (2013, s. 101).

\section{ZÁVĚR}

Přes významný vliv zkoumaných autorů je otázka, nakolik jsou tyto pozice charakteristické pro nominalisty 14 . století a pro další vývoj nominalistické tradice (např. $v$ dobře známém německém a pařížském okruhu), ponechána další diskuzi. Prezentace tří významných postockhamovských nominalistů však umožňuje jisté opatrné shrnutí v podobě následujících šesti pozorování:

Zaprvé, zdá se, že jednoznačnost transcendentálních výrazů je (z logických důvodů?) považována za výchozí pozici, zatímco pro jejich analogii je teprve třeba uvést důkazy. Dokladem je tendence zkoumaných nominalistických autorů ptát se, „co brání “ jednoznačnosti (quid prohibet), spíše nežli postupovat opačným směrem a dospívat $\mathrm{k}$ analogii přes vyvrácení víceznačnosti.

Zadruhé, oproti realistickým autorům vykazují nominalisté tendenci k osamostatňování historicky sdružených otázek. Konkrétně, Buridan předpokládá, že problémy transcendentální a teologické analogie spolu nesouvisejí, ${ }^{82}$ a Marsilius z Inghen se domnívá, že spolu nesouvisejí transcendentalita a univocita.

Zatřetí, všichni tři zkoumaní autoři sice často odkazují na Aristotela, ale (mj.) nikdy podrobně nerozebírají argument pro aporii rodu (pouze uvádějí jeho důsledek, pro nějž pak formulují vlastní argumenty).

82 V Oresmeho připadě přinejmenším jedno lze diskutovat bez druhého, nicméně absence teologické analogie v jeho díle může být dána jednoduše kontextem přírodovědné práce. 
Začtvrté, problém analogie jsoucna je úzce vázán na ontologii akcidentů a (u Buridana a Marsilia z Inghen) specificky na teologický problém akcidentů separovaných. ${ }^{83}$ Obecně tvoří vyjasnění ontologického statusu akcidentů podstatnou část řešení problému analogie jsoucna. Připisování slabého ontologického statusu akcidentům koreluje s analogickým pojetím jsoucna. Krajními póly u zkoumaných nominalistických autorů jsou Buridanova teze, že (ontologicky „silné“) separované akcidenty a substance mohou být označovány jednoznačným pojmem jsoucna, a Oresmeho analogické pojetí jsoucna spojené s chápáním akcidentů jako parametrů logického prostoru „obývaného" substancemi.

Zapáté, v nominalistickém pojetí je scientia transcedens „ve skutečnosti“ aplikovanou sémantikou (resp. v některých případech pragmatikou). Tato teze je pochopitelně přehnaná, protože celá ontologie není v nominalistickém podání redukována na sémantiku, nicméně poskytuje dobrý obrázek diskuze o výsostně metafyzickém problému, jímž je analogie jsoucna. Zatímco u Tomáše byla zásadním momentem argumentu pro teologickou analogii určitá teorie kauzality a předpoklad hierarchizované reality, nominalističtí autoři popírají, že by hierarchie z hlediska nějaké formy nobility sehrávala jakoukoli roli v určení toho, zda je výraz analogický. ${ }^{84}$

83 Obecným přehledem různých scholastických přistupů k ontologii akcidentů se z nedávné literatury zabývá Pasnau 2012, s. $179-278$.

84 Lze oprávněně namítnout, že tato část nominalistické pozice není dostatečně
Podobně u nominalistického autora sehrává roli řešení aporie rodu odkazem na modality existence analýza sémantického rozdílu substanciálními a akcidentálními termíny. Podobný status mají „argumenty z mluvčího“: dokázat analogičnost pojmu znamená pro nominalistu dokázat jeho obecnost a to, že má primární a sekundární význam (ve specifickém smyslu). A dokázat tuto strukturovanost významu lze jednoduše tak, že položíme mluvčímu otázku, co je to „jsoucno“, a mluvčí odpoví „substance“ (resp. udá příklad substanciální entity). Tím je dokázáno, že výraz „jsoucno“ je sice aplikovatelný i na akcidenty, ale primárně označuje substance. To společně s předchozí poznámkou ukazuje na další zajímavý rys tohoto přístupu k analogii: jedná se o přístup bottom-up spíše nežli top-down; analogie je odvozována z kategoriální analýzy (sémantické a ontologické), spíše nežli aby byla samostatným tématem transcendentální analýzy, z níž budou odvozeny určité důsledky pro (re-)interpretaci kategoriální analýzy.

Zašesté - a toto je velmi předběžná poznámka: užitečnost historické nálepky „nominalista“ by se neměla přeceňovat. Dokonce i pomineme-li Ockhama, který nezapadá do zde prezentovaného souboru, přes výrazné styčné body zde nacházíme tři odlišné koncepce. Termín „nominalista“ označuje (v daném období) ${ }^{85}$ jen určitou pozici v otázce ontologického statusu abstraktních vlastností

vyargumentována, ale to je pro tuto chvíli vedlejší.

85 Dějiny termínu „nominalismus“ v předockhamovském období, jak známo, na- 
a jeho klasifikační potenciál v dalších otázkách, a to dokonce i otázkách ontologických, je velmi omezený. ${ }^{86} \mathrm{Je}$-li toto pozorování oprávněné i v širším souboru autorů, naznačovalo by to modulárnost středověkých teorií. To by konečně znamenalo, že středověké bádání by mělo být připraveno na setkávání se s aliancemi autorů, které jsou z hlediska sporu o univerzálie nepravděpodobné.

bízejí ještě jiný obraz (Courtenay 2008, s. 23-87).

86 Existují pravděpodobně ještě další oblasti ontologie, které dokládaji totéž, jako je vztah (resp. neexistence vztahu) mezi pozicí ve sporu o univerzálie a prístupem k otázce distinkce mezi esencí a existencí; tato otázka pochopitelně přesahuje meze této studie. 


\section{BIBLIOGRAFIE}

Aertsen, J. (2012). Medieval Philosophy as Transcendental Thought: From Philip the Chancellor (ca. 1225) to Francisco Suárez. Leiden: Brill.

Albert ze Saska (1988). Quaestiones in artem veterem (ed. A. M. García). Maracaibo: Universidad del Zulia.

Albert ze Saska (2010). Logik (přel. H. Berger). Hamburg: Meiner.

Aristotelés (1985). The Complete Works of Aristotle, Volume II (ed. J. Barnes, přel. W. D. Ross). Princeton: Princeton University Press.

Aristoteles Latinus (1995). „Metaphysica (recensio et translatio Guillelmi de Moerbeka)“. In: G. Vuillemin-Diem (ed.), Aristoteles Latinus XXV3.2. Leiden: Brill.

Aristotelés (2008). Metafyzika (přel. A. Kř́íz). Praha: Petr Rezek.

Ashworth, E. J. (2013). „Medieval Theories of Analogy“. In: E. N. Zalta (ed.), The Stanford Encyclopedia of Philosophy (Winter 2013 Edition).

$\mathrm{URL}=<$ https://plato.stanford.edu/archives/win2013/entries/analogy-medieval/>.
Bakker, P. J. J. M. (2000). „Aristotelian Metaphysics and Eucharistic Theology. John Buridan and Marsilius of Inghen on the Ontological Status of Accidental Being. “In: J. M. M. H. Thijssen, J. Zupko (eds.), The Metaphysics and Natural Philosophy of John Buridan. Leiden: Brill, s. 247-264.

Bakker, P. J. J. M. (2002). „Inhérence, univocité et séparabilité des accidents eucharistiques“. In: J.-L. Solère, Z. Kaluza (eds.), La servante et la consolatrice. La philosophie dans des rapports avec la théologie au Moyen Âge (Textes et Traditions 3). Paris: Vrin, s. 193-245.

Buridan, J. (1995). Johannes Buridanus: Summulae de suppositionibus (ed. R. van der Lecq). Turnhout: Brepols.

Buridan, J. (2002). „Quaestiones in Metaphysicam (secundum ultimam lecturam), Liber IV, quaestio 6“. In: J.-L. Solère, Z. Kaluza (eds.), La servante et la consolatrice. La philosophie dans des rapports avec la théologie au Moyen Âge (Textes et Traditions 3). Paris: Vrin, s. 219-232. 
Buridan, J. (2008). Lectura Erfordiensis in I-VI Metaphysicam, together with the 15th-century Abbreviatio Caminensis: Introduction, Critical Edition and Indexes (ed. L. M. de Rijk). Turnhout: Brepols.

Courtenay, W. J. (2004). „The University of Paris at the Time of Jean Buridan and Nicole Oresme“. Vivarium 42, s. 3-17.

Courtenay, W. J. (2008). Ockham and Ockhamism. Studies in the Dissemination and Impact of his Thought. Leiden: Brill.

Jan Duns Scotus (1895). „Quaestiones quodlibetales". In: Joannis Duns Scoti doctoris subtilis, ordinis minorum Opera omnia tom. 25. Paris.

Jan Duns Scotus (1954). Ordinatio. Liber primus, distinctio tertia. Opera omnia III (eds. C. Balic, M. Bodewig, S. Buselic, P. Capkun-Delic, B. Hechich, I. Juric, B. Korosak, L. Modric, I. Montalverne, S. Nanni, B. Pergamo, F. Prezioso, I. Reinhold, O. Schäfer). Città del Vaticano: Typis Polyglottis Vaticanis.

Dvořák, P. (ed.) (2007a). Analogie ve filosofii a teologii. Brno: Centrum pro studium demokracie a kultury.
Dvořák, P. (2007b). „Sémantika analogie u Tomáše a v tomismu“. In: P. Dvořák, Analogie ve filosofii a teologii. Brno: Centrum pro studium demokracie a kultury, s. 91-106.

Dvořák, P. (2007c). Tomáš a Kajetán o analogii jmen. Praha: Krystal OP.

Hoenen, M. (2017). „Marsilius of Inghen“. In: E. N. Zalta (ed.), The Stanford Encyclopedia of Philosophy (Spring 2017 Edition). $\mathrm{URL}=<$ https://plato.stanford.edu/archives/spr2017/entries/marsilius-inghen/>.

Chabada, M. (2007). „K niektorým argumentom $v$ prospěch jednoznačnosti pojmu súcna u Jána Dunsa Scota“. In: P. Dvořák (ed.), Analogie ve filosofii a teologii. Brno: Centrum pro studium demokracie a kultury, s. 119-140.

Jindřich z Ghentu (1981). „Quodlibet X“. In: R. Macken (ed.), Henrici de Gandavo Opera Omnia 14. Leuven: Leuven University Press.

Kirschner, S. (2013). „Nicole Oresme“. In: E. N. Zalta (ed.), The Stanford Encyclopedia of Philosophy (Fall 2013 Edition). $\mathrm{URL}=<$ https://plato.stanford.edu/archives/fall2013/entries/nicole-oresme/>. 
Kok, F. J. (2013). „John Buridan's Commentary on Metaphysics“. In: G. Galluzzo, F. Amerini (eds.), A Companion to the Latin Medieval Commentaries on Aristotle's Metaphysics. Leiden: Brill, s. 495-549.

Kretzmann, N., Kenny, A. J. P., Pinborg, J. (eds.) (1988). The Cambridge History of Later Medieval Philosophy: from the Rediscovery of Aristotle to the Disintegration of Scholasticism, 1100-1600. Cambridge: Cambridge University Press.

Leinsle, U. G. (2002). „Rodrigo de Arriaga im Streit um modale Entitäten“. In: J. Beneš, P. Glombíček, V. Urbánek (eds.), Bene Scripsisti: Filosofie od středověku $k$ novověku. Sborník k sedmdesátinám Stanislava Sousedíka. Praha: Filosofia, s. 161-190.

Marsilius of Inghen (2000). Quaestiones super quattuor libros Sententiarum, Vol. 2: Super primum, quaestiones 8-21 (eds. G. Wieland, M. Santos Noya, M. J. F. M. Hoenen, M. Schulze). Leiden: Brill.

Marsilius z Inghen (2002). „Quaestiones in Metaphysicam, Liber IV, quaestio 5“. In: J.-L. Solère, Z. Kaluza (eds.), La servante et la consolatrice. La philosophie dans des rapports avec la théologie au Moyen Âge (Textes et Traditions 3). Paris: Vrin, s. 233-245.

Marsilius z Inghen (2008). Quaestiones super librum Praedicamentorum Aristotelis (ed. H. Wojtczak). Lublin: Towarzystwo Naukowe Katolickiego Uniwersytetu Lubelskiego Jana Pawła II.

Marsilius z Inghen (2014). Quaestiones super Isagogen Porphyrii (ed. H. Wojtczak). Lublin: Towarzystwo Naukowe Katolickiego Uniwersytetu Lubelskiego Jana Pawła II.

Marsilius of Inghen (2015). Quaestiones super quattuor libros Sententiarum, Vol. 3: Super primum, quaestiones 22-37 (eds. M. J. F. M. Hoenen, M. Erne). Leiden: Brill.

Michael, B. (1985). Johannes Buridan: Studien zu seinem Leben, seinen Werken und zu Rezeption seiner Theorien im Europa des späten Mittelalters, 2 sv. dizertační práce (Freie Universität Berlin). Berlin.

Novák, L. (2007). „Analogický pojem po Scotovi? Kritika tomistické teorie analogie“. In: P. Dvořák (ed.), Analogie ve filosofi a teologii. Brno: Centrum pro studium demokracie a kultury, s. 141-162. 
Novák, L. (2011). Scire Deum esse: Scotův důkaz Boží existence jako vrcholný výkon metafyziky jakožto aristotelské vědy. Praha: Kalich.

Nuchelmans, G. (1973). Theoreis of the Proposition. Ancient and Medieval Conceptions of the Bearers of Truth and Falsity. Amsterdam: North-Holland Publishing Co.

Nuchelmans, G. (1980). Late-Scholastic and Humanist Theories of the Proposition. Amsterdam: Royal Netherlands Academy.

Nuchelmans, G. (1988). „The Semantics of Propositions". In: N. Kretzmann, A. J. P. Kenny, J. Pinborg (eds.), The Cambridge History of Later Medieval Philosophy: from the Rediscovery of Aristotle to the Disintegration of Scholasticism, 1100-1600. Cambridge: Cambridge University Press, s. 197-210.

Mikuláš Oresme (2013). Questiones super Physicam (Books I-VII) (eds. S. Caroti, J. Celeyrette, S. Kirschner, E. Mazet). Leiden: Brill.

Pasnau, R. (2012). Metaphysical Themes 1274-1671. Oxford: Clarendon Press.
Pavel z Benátek (1978). Logica magna: Part II, Fascicule 6: Tractatus de veritate et falsitate propositionis et tractatus de significato propositionis (ed. F. del Punta, přel. M. M. Adams). Oxford: Oxford University Press.

Pelletier, J. (2013). William of Ockham on Metaphysics. The Science of Being and God. Leiden: Brill.

Perler, D. (1990). Satztheorien. Texte zur Sprachphilosophie und Wissenschaftstheorie im 14. Jahrhundert. Darmstadt: Wissenschaftliche Buchgesellschaft.

Perler, D. (1992). Der propositionale Wahrheitsbegriff im 14. Jahrhundert. Berlin: De Gruyter.

Porphyrius (1998). Isagoge (přel. Boëthius, přel. a ed. A. de Libera, ed. A.-P. Segonds). Paris: Vrin.

Read, S. (2015). „Medieval Theories: Properties of Terms“. In: E. N. Zalta (ed.), The Stanford Encyclopedia of Philosophy (Spring 2015 Edition).

$\mathrm{URL}=<$ https://plato.stanford.edu/archives/spr2015/entries/medieval-terms/>. 
Sousedík, S. (1989). Jan Duns Scotus: doctor subtilis a jeho čeští žáci. Praha: Vyšehrad.

Tomáš Akvinský ${ }^{87}$ (1929). Scriptum super libros Sententiarum magistri Petri Lombardi episcopi Parisiensis, tom. 1 (ed. P. Mandonnet). Paris: Lethielleux.

Tomáš Akvinský (1961). Liber de veritate catholicae Fidei contra errores infidelium seu Summa contra Gentiles, tom. 2-3 (eds. P. Marc, C. Pera, P. Caramello). Roma: Marietti.

Tomáš Akvinský (1965). Quaestiones disputatae, tom. 2: Quaestiones disputatae de potentia (ed. P. M. Pession). Roma.
Tomáš Akvinský (2003). O pravdě. O mysli. Praha: Krystal.

Weijers, O. (1994-2012). Le travail intellectuel à la Faculté des arts de Paris: textes et maîtres (c. 1200-1500), 9 sv. Turnhout: Brepols.

Zupko, J. (2014). „John Buridan“. In: E. N. Zalta (ed.), The Stanford Encyclopedia of Philosophy (Spring 2014 Edition). $\mathrm{URL}=<$ https://plato.stanford.edu/archives/spr2014/entries/buridan/>. 